\title{
COMPARATIVE STUDIES ON THE MICROBIAL LOAD OF FLAVOURED AND UNFLAVOURED DRINKING YOGHURT
}

\author{
Aly, Salwa, A. ${ }^{1}$ \& Galal, E.A. ${ }^{2}$ \\ ${ }^{1}$ Food Hygiene Dept., Fac. of Veterinary Medicine, Cairo Univ., Cairo, Egypt. \\ ${ }^{2}$ Dairy Science Dept., Fac. of Agric., Fayoum Univ., Egypt.
}

\begin{abstract}
To assess the accuracy and helpfulness of plain and flavoured drinking yoghurt, one hundred and fifty random samples (thirty each) of plain, strawberry, mango, banana and orange were collected from different supermarkets in Cairo and Giza Governorates, Egypt. The examined samples were analyzed to assess and compare the microbiological quality of plain and flavoured drinking yoghurt samples before their expiry or sell-by date. The data obtained revealed that, aerobic spore former count were determined in different types of examined plain, strawberry, mango, banana and orange samples with a mean values of $6.4 \times 10^{3} \pm 1.1 \times 10^{2}, 1.3 \times 10^{5} \pm 2.1 \times 10^{4}, 3.2 \times 10^{6} \pm 4.3 \times 10^{5}, 6.9 \times 10^{5} \pm 7.2 \times 10^{4}$ and $4.2 \times 10^{6} \pm 6.6 \times 10^{5}$, respectively. Mould and yeast counts were detected in 30, 100, 100, 100 and 90\% of the examined samples. Coliforms, Enterococci and, Staphylococci were detected in different kinds of examined flavoured drinking yoghurt. Pseudomonas and Aeromonas as well as Bacillus cereus were present in the examined samples with percentages ranged from 23.3 to $66.7 \%$ and 0 to $36.6 \%$, respectively. Salmonella and Yersinia were not detected in all examined samples. The survival of Listeria monocytogenes in drinking yoghurt stored at refrigerator for 30 days was investigated. The public health significance and economical importance of different microbial groups as well as recommended hygienic measures were discussed.
\end{abstract}

Keywords: drinking yoghurt, flavoured yoghurt, yeasts, moulds, Salmonella, Listeria monocytogenes..

\section{INTRODUCTION}

In recent years, there has been a large increase in the popularity of fermented milk products. The consumers search for new and unique fermented milks to maintain the healthy eating habits (Adhikari, et al., 2000, Pereg, et al., 2005).

Drinking yoghurt is delicious cultured stirred yoghurt recently prevails in the Egyptian markets. It is one of the fermented milk products which consumed by large segments of the population either as a part of diet or as a refreshing beverage. It is nutritiously balanced food containing almost all the nutrients present in milk as well as valuable therapeutic properties (Bartram et al., 1994, Yuceer et al., 2001, Lubbers et al., 2004).

The preparation of this product involves stirring of the coagulum after fermentation, diluted with fruit juices, fruit syrup, sugar and other flavouring materials to obtain drinkable properties followed by aseptic packaging and then cooled (Varnam \& Sutherland, 1994, Harte et al., 2003).

Due to the fact that drinking yoghurt is purchased by the consumer on the basis of flavour and ingredients, there are several different flavours used in their manufacture which may be plain (natural) or in a wide variety of flavours as strawberry, apricot, apple, banana or mango. Generally, these flavours are added to drinking yoghurt after pasteurization and fermentation have been completed. Therefore, microbial hazard may be of considerable importance to drinking yoghurt industry (Beal, et al., 1999, Kozlowska et al., 2002, Martin et al., 2004).

Plain and flavoured fermented milks are associated with several human health benefits. In addition to being palatable and nutritious, the starter culture bacteria help to maintain a wellbalanced microflora (Gabriela, et al., 1998, De Moreno \& Perdigon, 2004). This positive influence on the gut may contribute to decrease diarrhea, increase lactose tolerance in susceptible 
individuals, decrease incidence of colon cancer, prevent DNA damage induced by the carcinogens, improve the immune response and inhibit serum cholesterol level (Gilliland, 1998, Wollowski, et al., 1999, Ott et al., 2000, Kozlowska et al., 2002, Seppo, et al., 2003, Moreno, 2005).

It was believed that, low $\mathrm{pH}$ and low storage temperature of drinking fermented milk may protect from pathogenic bacteria but some pathogens as well as moulds and yeasts may get entry to the product either before or post processing leading to economical and public health hazards. Yeasts find good medium and suitable environment for growth and multiplication with consequent alteration in its quality (Garbutt, 1998, WHO, 2000). Some yeasts ferment lactose into carbon dioxide and ethanol leading to blown cartons, off flavour and odour. The major source of contamination is the added fruit purees which is often contaminated by unsatisfactory handling procedures. In addition, presence of these organisms indicating shortage in the process of pasteurization or post pasteurization contamination (Kurmann et al., 2000, AlKadamany et al., 2002, Kora, et al., 2004).

In contrast to the extensive bibliography available on yoghurt and other fermented milks, there is an almost lack of microbial evaluation of flavoured and unflavoured drinking yoghurt. Nowadays, the increase demand of Egyptian markets for drinking yoghurt for children and elderly has made its microbiological quality of primary concern. Therefore, this work was planned to evaluate the effect of different additives (flavours) on actual microbiological hazard of flavoured drinking yoghurt and to examine the ability of Listeria monocytogenes to survive in plain and flavoured drinking yoghurt.

\section{MATERIALS AND METHODS Materials}

One hundred and fifty random samples (thirty each) of flavoured mix with strawbery, mango, banana, orange and unflavoured drinking yoghurt stored in refrigerator, in its retail containers were collected from different dairy shops and supermarkets from Cairo and Giza governorates. The samples were collected at the first or second day of production (fresh) samples. All samples have a shelf life time of 14 days when refrigerated at $4^{\circ} \mathrm{C}$ as recommended by the producing companies. The collected samples were transported to the laboratory in an insulating icebox with a minimum of delay to be immediately examined for microbial load (Messer et al., 1992).

\section{Methods}

Samples were prepared as the technique described by Messer et al. (1992).

\section{Enumeration of different types of micro- organisms:}

Aerobic spore formers counts was carried out using the technique recommended by Marshall (1992).

Yeast and mould counts were applied according to Lodder (1990). Macroscopic and microscopic identification of the isolated moulds according to Samson et al., (1995) and Pitt \& Hocking (1997) while identification of yeasts strains according to the method applied by Elzataar, et al. (1990) and Rama et al. (1998).

Coliforms count was carried out using the most probable number (MPN) technique as described by Hitchins et al. (1992). Enterococci, Staphylococci, Pseudomonas and Aeromonas counts were undertaken according to MSF (1996), Robinson (1990) and Colins et al. (1995), respectively.

Isolation and identification of Salmonella (Flowers et al., 1992), Yersinia entercolitica (Donald \& George, 1992) and Bacillus cereus (Granum, 1997) were also investigated.

\section{Survival of Listeria monocytogenes:}

Bacterial culture: Listeria monocytogenes ATCC 1037 serotype 4b was used in this study. A stock culture of the organism was obtained from Institute for Microbiology (Hannover University, Germany) and maintained in vials. Inoculum from the vial was transferred into tryptic soy broth supplemented with yeast extract (TSBYE) and stored at $4^{\circ} \mathrm{C}$. Fresh culture was grown on TSBYE at $37^{\circ} \mathrm{C}$ for $18-24 \mathrm{hr}$. Serial dilutions were prepared with buffered peptone water $(0.1 \%)$ and bacterial count were enumerated on modified Oxford agar media. Twenty five grams of the plain and strawberry flavoured drinking yoghurt were aseptically transferred into stomacher bags and kept at $4^{\circ} \mathrm{C}$ for 30 days. Uninoculated control samples were plated on Oxford agar media. Test samples were inoculated by $6.6 \times 10^{6} \mathrm{CFU} / \mathrm{ml}$. Samples were mixed to ensure the proper mixing of the samples. The $\mathrm{pH}$ of the samples was measured with ORION $\mathrm{pH}$ meter (model 520, Orion Research, Inc, Bevery, Mass). Samples were ex- 
amined every 5 days for a total storage time of 30 days at $4^{\circ} \mathrm{C}$. The technique adopted according to Tipparaju et al. (2004).

\section{Statistical analysis}

The ANOVA test (Analysis of Variance) was applied at $95 \%$ to point out if there were significant differences between the different microbiological counts by Duncan's multiple range test (SPSS, 1993).

\section{RESULTS AND DISCUSSION}

Results presented in Table (1) showed that Aerobic spore formers were present in plain and flavoured drinking yoghurt samples in a percentages of 20,96.7, 83.3, 100 and $60 \%$ with a mean values of $6.4 \times 10^{3} \pm 1.1 \times 10^{2}, 1.3 \times$ $10^{5} \pm 2.1 \times 10^{4}, \quad 3.2 \times 10^{6} \pm 4.3 \times 10^{5}, \quad 6.9 \times 10^{5} \pm 7.2 \times$ $10^{4}$ and $4.2 \times 10^{6} \pm 6.6 \times 10^{5} \mathrm{CFU} / \mathrm{ml}$ for plain, mango, strawberry, banana and orange drinking yoghurt samples, respectively. There was significant difference between the plain and different kinds of flavoured samples $(\mathrm{P}<0.05)$. The higher occurrence of aerobic spore formers in drinking yoghurt may be due to their heat resistance to pasteurization. They produce heat resistant proteolytic and lipolytic enzymes which may cause spoilage in the refrigerated products (Varnam \& Sutherland, 1994, Armesto \& Alastair, 1997).

The data given in Table (2) illustrate that yeasts and moulds were detected in 30,100 ,
100, 100 and $90 \%$ of the examined drinking yoghurt samples with a mean values of $2.4 \times 10^{3} \pm 1.1 \times 10^{2}, 6.1 \times 10^{7} \pm 8.1 \times 10^{6}, 3.3 \times 10^{6} \pm$ $4.2 \times 10^{4}, 7.3 \times 10^{6} \pm 5.9 \times 10^{5}, 3.5 \times 10^{7} \pm 4.8 \times 10^{5}$ $\mathrm{CFU} / \mathrm{ml}$ for plain, mango, strawberry, apricot and orange samples, respectively. There was significant difference between the plain and different kinds of flavoured samples $(\mathrm{P}<0.05)$ while there was no significant difference between mango, strawberry, banana and orange samples. Yeast and mould counts should not exceed $10 \mathrm{CFU} / \mathrm{ml}$ according to Egyptian Standard (Egyptian Standards, 2005). All samples of flavoured drinking yoghurt were heavily contaminated with moulds and yeasts. The high mould and yeast counts may be attributed to inadequate hygienic measures in production or the use of bad quality flavoured materials (Varnam \& Sutherland, 1994, Graciela, et al., 2001). Results presented in Table (3) revealed that the most common mould species isolated from drinking yoghurt samples are belonging to genera : Penicillium (33.3, 66.7, 80, 63.3 and $77.8 \%$ ) which represented by $P$. spinulosum (16.6, 36.7, 33.3, 43.3 and 59.3\%), P. expansum $(10,20,26.7,16.7$ and 18.5\%) and $P$. digitatum (6.6, 10, 20, 3.3 and 0\%), Aspergillus (23.3, 56.7, 40, 53.3 and 48.1\%) which represented by A. flavus (10, 25, 23.3, 30, 29.6\%), A. niger $(10,10,13.3,20,18.5)$ and $A$. ochracious (3.3, 15, 3.4, 3.3 and 0\%), Bysochlamys which represented by B. fulva (16.6, 40, 30, 23.3 and

Table 1: Total aerobic spore former count in examined drinking yoghurt samples (n=30) CFU/ml

\begin{tabular}{llllll}
\hline \multirow{2}{*}{ Type } & \multicolumn{2}{c}{ Positive samples } & \multirow{2}{*}{ Min. } & Max. & Mean \\
\cline { 2 - 4 } & \multicolumn{2}{c}{ No. } & \% & & \\
\hline Plain & 6 & 20 & 10 & $2.2 \times 10^{5}$ & $6.4 \times 10^{3} \pm 1.1 \times 10^{2 \mathrm{a}}$ \\
Mango & 29 & 96.7 & 100 & $3.0 \times 10^{7}$ & $1.3 \times 10^{5} \pm 2.1 \times 10^{4 \mathrm{~b}}$ \\
Strawberry & 25 & 83.3 & 90 & $8.0 \times 10^{7}$ & $3.2 \times 10^{6} \pm 4.3 \times 10^{5 \mathrm{~b}}$ \\
Banana & 30 & 100 & 90 & $6.5 \times 10^{7}$ & $6.9 \times 10^{5} \pm 7.2 \times 10^{4 \mathrm{~b}}$ \\
Orange & 18 & 60 & 10 & $1.9 \times 10^{8}$ & $4.2 \times 10^{6} \pm 6.6 \times 10^{5 \mathrm{~b}}$ \\
\hline
\end{tabular}

CFU: colony forming units

Means of different superscript (a and b) considered significantly different at 95\%.

Table 2: Total yeast and mould counts in examined drinking yoghurt samples $(n=30)$

\begin{tabular}{llllll}
\hline \multirow{2}{*}{ Type } & \multicolumn{2}{c}{ Positive samples } & \multirow{2}{*}{ Min. } & Max. & Mean \\
\cline { 2 - 4 } & No. & \% & & & \\
\hline Plain & 10 & 30 & 100 & $4.6 \times 10^{5}$ & $2.4 \times 10^{3} \pm 1.1 \times 10^{2 \mathrm{a}}$ \\
Mango & 30 & 100 & $3.0 \times 10^{2}$ & $1.2 \times 10^{9}$ & $6.1 \times 10^{7} \pm 8.1 \times 10^{6 \mathrm{~b}}$ \\
Strawberry & 30 & 100 & $2.1 \times 10^{2}$ & $9.7 \times 10^{8}$ & $3.3 \times 10^{6} \pm 4.2 \times 10^{4 \mathrm{~b}}$ \\
Banana & 30 & 100 & $1.6 \times 10^{2}$ & $8.0 \times 10^{8}$ & $7.3 \times 10^{6} \pm 5.9 \times 10^{5 \mathrm{~b}}$ \\
Orange & 27 & 90 & $5.0 \times 10^{2}$ & $9.9 \times 10^{9}$ & $3.5 \times 10^{7} \pm 4.8 \times 10^{5 \mathrm{~b}}$ \\
\hline
\end{tabular}

Means of different superscript (a and b) considered significantly different at 95\%. 
Table 3: Incidence of isolated moulds in examined drinking yoghurt samples

\begin{tabular}{|c|c|c|c|c|c|c|c|c|c|c|}
\hline \multirow{2}{*}{ Species } & \multicolumn{2}{|c|}{ Plain } & \multicolumn{2}{|c|}{ Mango } & \multicolumn{2}{|c|}{ Strawberry } & \multicolumn{2}{|c|}{ Banana } & \multicolumn{2}{|c|}{ Orange } \\
\hline & No. & $\%$ & No. & $\%$ & No. & $\%$ & No. & $\%$ & No. & $\%$ \\
\hline Penicillium & 10 & 33.3 & 20 & 66.7 & 24 & 80 & 19 & 63.3 & 21 & 77.8 \\
\hline P. spinulosum & 5 & 16.6 & 11 & 36.7 & 10 & 33.3 & 13 & 43.3 & 16 & 59.3 \\
\hline P. expansum & 3 & 10 & 6 & 20.0 & 8 & 26.7 & 5 & 16.7 & 5 & 18.5 \\
\hline P. digitatum & 2 & 6.6 & 3 & 10.0 & 6 & 20.0 & 1 & 3.30 & 0 & 0 \\
\hline Aspergillus & 7 & 23.3 & 15 & 56.7 & 12 & 40 & 16 & 53.3 & 13 & 48.1 \\
\hline A. Flavus & 3 & 10 & 10 & 25 & 7 & 23.3 & 9 & 30 & 8 & 29.6 \\
\hline A. niger & 3 & 10 & 4 & 10 & 4 & 13.3 & 6 & 20 & 5 & 18.5 \\
\hline A. ochracious & 1 & 3.3 & 1 & 15 & 1 & 3.4 & 1 & 3.3 & 0 & 0 \\
\hline Bysochlamys fulva & 5 & 16.6 & 10 & 40 & 9 & 30 & 7 & 23.3 & 0 & 0 \\
\hline Euepenicillium labidosum & 0 & 0 & 9 & 30 & 6 & 20 & 1 & 3.3 & 0 & 0 \\
\hline Talaromyces flavus & 0 & 0 & 8 & 20 & 4 & 13.3 & 0 & 0 & 8 & 29.6 \\
\hline
\end{tabular}

0\%), Euepenicillium which represented by $E$. labidosum (0, 30, 20, 3.3 and 0\%) and Talaromyces which represented by $T$. flavus $(0,20$, 13.3, 0 and 29.6\%) in examined plain, mango, strawberry, apricot and orange samples, respectively. Results presented in Table (4) showed that the isolated yeasts from the examined drinking yoghurt samples could be identified as genera Candida (30, 73.3, 63.3, 50 and 37\%) which represented by C. albicans (13.3, 53.3, 33.3, 23.3 and 18.5\%), C. lipoliticum (10, 10, 20, 13.3 and 11.1), C. curvataq (6.6, 6.7, 6.7, 10 and $7.4 \%$ ) and $C$. tenius (0, 3.3, 3.3, 3.3 and 0$)$, Torulopsis (0, 60, 40, 43.3 and 29.6) represented by $T$. versatilis $(0,33.3,20,40$ and $22.2 \%)$, T. ernobii (0, 26.7, 20, 3.3 and 7.4\%) and Saccharomyces (20,30, 23.3, 16.6 and $22.2 \%$ ) which represented by $S$. cervisae (13.3, 16.7, 13.3, 13.3 and $11.1 \%$ ) and S. farinosum $(6.7,13.3,10,3.3$ and 11.1) in examined plain, mango, strawberry, banana and orange drinking yoghurt samples, respectively. The presence of Bysochlamys, Euepenicillium, Talaromyces and Saccharomyces in flavoured drinking yoghurt may be due to their frequent presence in flavouring materials (fruit juices and concentrates) as well as their high resistance to heat treatment (Gourama \& Bullerman, 1995, Robert, 1997, Li \& Li, 1998). Therefore the producers should be aware with those flavouring materials. As moulds are widely distributed as environmental contaminants of air, water and soil, they are responsible for spoilage of drinking yoghurt which causes economical losses. The public health importance of mould has been emphasized as certain types of moulds produce mycotoxins which implicated in liver cancer (Chapman, 2003). The high count of moulds and yeasts in all examined samples may be due to any of the following reasons: high count in

Table 4: Incidence of yeast species in examined samples

\begin{tabular}{llllllllllll}
\hline \multirow{2}{*}{ Species } & \multicolumn{2}{c}{ Plain } & \multicolumn{2}{c}{ Mango } & \multicolumn{2}{c}{ Strawberry } & \multicolumn{2}{c}{ Banana } & \multicolumn{2}{c}{ Orange } \\
\cline { 2 - 11 } & No. & \% & No. & \% & No. & \% & No. & \% & No. & \% \\
\hline Candida & 9 & 30 & 22 & 73.3 & 19 & 63.3 & 15 & 50 & 10 & 37.0 \\
C. albican & 4 & 13.3 & 16 & 53.3 & 10 & 33.3 & 7 & 23.3 & 5 & 18.5 \\
C. lipoliticum & 3 & 10 & 3 & 10.0 & 6 & 20.0 & 4 & 13.3 & 3 & 11.1 \\
C. curvata & 2 & 6.6 & 2 & 6.7 & 2 & 6.7 & 3 & 10.0 & 2 & 7.4 \\
C. tenius & 0 & 0 & 1 & 3.3 & 1 & 3.3 & 1 & 3.3 & 0 & 0 \\
Torulopsis & 0 & 0 & 18 & 60.0 & 12 & 40 & 13 & 43.3 & 8 & 29.6 \\
T.versatilis & 0 & 0 & 10 & 33.3 & 6 & 20 & 12 & 40 & 6 & 22.2 \\
T. ernobii & 0 & 0 & 8 & 26.7 & 6 & 20 & 1 & 3.3 & 2 & 7.4 \\
Saccharomyces & 6 & 20 & 9 & 30.0 & 7 & 23.3 & 5 & 16.6 & 6 & 22.2 \\
S. cervisae & 4 & 13.3 & 5 & 16.7 & 4 & 13.3 & 4 & 13.3 & 3 & 11.1 \\
S. farinosum & 2 & 6.7 & 4 & 13.3 & 3 & 10.0 & 1 & 3.3 & 3 & 11.1 \\
\hline
\end{tabular}


raw materials, ineffective processing methods, ineffective sanitizing methods or faulty storage of the products. Therefore sanitary control measures should be adapted to dairy processing plants by application of HACCP system on processing, packaging, storage and distribution of such products (Spreer \& Mixa, 1998, Ray, 2004).

The data recorded in Table (5) revealed that coliforms count were presented in percentages of 13.3, 50, 86.7, 76.7 and $56.7 \%$ with an average of $1.9 \times 10^{3} \pm 2 \times 10^{2}, 5.0 \times 10^{5} \pm 2.9 \times 10^{4}$, $4.7 \times 10^{6} \pm 8.5 \times 10^{5}, 1.0 \times 10^{6} \pm 1.7 \times 10^{5}$ and $9.9 \times 10^{6}$ $\pm 4.8 \times 10^{5} \mathrm{CFU} / \mathrm{ml}$ for plain, mango, strawberry, banana and orange drinking yoghurt samples, respectively. There was significant difference between the plain and different kinds of flavoured samples $(\mathrm{P}<0.05)$. Coliform organisms may be implicated in food illness among the consumers. The additives were the most important source of contamination with Coliforms. In general, it may be used as indicator for processing sanitation. Moreover up to $30 \%$ of people in industrialized countries and millions of people in developing countries suffer from food borne illness (WHO, 2000).

Regarding the data presented in Table (6) Enterococci was existed in a percentages of 0 , $60,50,63.3$ and $50 \%$ of the examined samples with a mean values of $0,2.2 \times 10^{4} \pm 0.33 \times 10^{2}$,
$4.7 \times 10^{4} \pm 9.9 \times 10^{3}, 8.6 \times 10^{4} \pm 0.4 \times 10^{2}$ and $5.2 \times 10^{4}$ $\pm 2.5 \times 10^{2} \mathrm{CFU} / \mathrm{ml}$ for plain, mango, strawberry, banana and orange drinking yoghurt samples, respectively. There was significant difference between the plain and different kinds of flavoured samples $(\mathrm{P}<0.05)$. The Enterococci resist heat treatment and can grow at wide range of temperature. They are normal inhabitants of the alimentary tract of man and animals, from which such organisms can find its way into milk and drinking yoghurt. Therefore these organisms are useful indicators of the possible presence of enteric pathogens. Furthermore, may help in assessing the standard of hygiene in dairy factories (Rodriguez et al., 2003).

Results demonstrated in Table (7) revealed that mean values of Staphylococci count in different kinds of drinking yoghurt were 1.5× $10^{2} \pm 0.28 \times 10^{2}, 2.7 \times 10^{3} \pm 0.9 \times 10^{2}, 6.3 \times 10^{3} \pm 1.1 \times$ $10^{2}, \quad 4.4 \times 10^{3} \pm 0.1 \times 10^{2}$ and $5.0 \times 10^{3} \pm 2.5 \times 10^{2}$ $\mathrm{CFU} / \mathrm{ml}$ with percentages of 26.6, 53.3, 63.3, 56.6 and $60.0 \%$, respectively. For the examined mango, strawberry, banana and orange drinking yoghurt samples respectively. There was significant difference between the plain and different kinds of flavoured samples $(\mathrm{P}<0.05)$. Yoghurt may be subjected to contamination by different pathogens as Staphylococcus aureus which may get access before, during, or even after processing rendering the product unsafe for

Table 5: Total Coliform count in examined drinking yoghurt samples $(\mathrm{n}=30)$

\begin{tabular}{|c|c|c|c|c|c|}
\hline \multirow{2}{*}{ Type } & \multicolumn{2}{|c|}{ Positive samples } & \multirow{2}{*}{ Min. } & \multirow{2}{*}{ Max. } & \multirow{2}{*}{ Mean } \\
\hline & No. & $\%$ & & & \\
\hline Plain & 4 & 13.3 & 10 & $2.4 \times 10^{4}$ & $1.9 \times 10^{3} \pm 2 \times 10^{2 \mathrm{a}}$ \\
\hline Mango & 15 & 50 & 10 & $3.2 \times 10^{6}$ & $5.0 \times 10^{5} \pm 2.9 \times 10^{4 b}$ \\
\hline Strawberry & 26 & 86.7 & $1.0 \times 10^{2}$ & $9.1 \times 10^{7}$ & $4.7 \times 10^{6} \pm 8.5 \times 10^{5 b}$ \\
\hline Banana & 23 & 76.7 & $6.1 \times 10^{2}$ & $2.0 \times 10^{7}$ & $1.0 \times 10^{6} \pm 1.7 \times 10^{5 b}$ \\
\hline Orange & 17 & 56.7 & $1.9 \times 10^{2}$ & $7.0 \times 10^{6}$ & $9.9 \times 10^{6} \pm 4.8 \times 10^{5 b}$ \\
\hline
\end{tabular}

Means of different superscript (a and b) considered significantly different at 95\%.

Table 6: Statistical analytical results of Entercocci counts in examined stirred yoghurt samples (n=30)

\begin{tabular}{|c|c|c|c|c|c|}
\hline \multirow{2}{*}{ Type } & \multicolumn{2}{|c|}{ Positive samples } & \multirow{2}{*}{ Min. } & \multirow{2}{*}{ Max. } & \multirow{2}{*}{ Mean } \\
\hline & No. & $\%$ & & & \\
\hline Plain & 0 & 0 & 0 & 0 & $0^{\mathrm{b}}$ \\
\hline Mango & 18 & 60 & 100 & $2.1 \times 10^{5}$ & $2.2 \times 0^{4} \pm 0.33 \times 10^{2 a}$ \\
\hline Strawberry & 15 & 50 & 20 & $6.3 \times 10^{5}$ & $4.7 \times 0^{4} \pm 9.9 \times 10^{3 a}$ \\
\hline Banana & 19 & 63.3 & 10 & $2.4 \times 10^{5}$ & $8.6 \times 0^{4} \pm 0.4 \times 10^{2 \mathrm{a}}$ \\
\hline Orange & 15 & 50 & 10 & $1.9 \times 10^{5}$ & $5.2 \times 0^{4} \pm 2.5 \times 10^{2 a}$ \\
\hline
\end{tabular}

Means of different superscript (a and b) considered significantly different at 95\%. 
Table 7: Statistical analytical results of Staphylococci count in examined samples $(\mathbf{n}=30)$

\begin{tabular}{lcccccc}
\hline Type & \multicolumn{2}{c}{ Positive samples } & & Min. & Max. & Mean \\
\cline { 2 - 3 } & No. & \% & & & & \\
\hline Plain & 8 & 26.6 & 20 & $5 \times 10^{4}$ & $1.5 \times 10^{2} \pm 0.28 \times 10^{2 \mathrm{a}}$ \\
Mango & 16 & 53.3 & 20 & $4.0 \times 10^{5}$ & $2.7 \times 10^{3} \pm 0.9 \times 10^{2 \mathrm{~b}}$ \\
Strawberry & 19 & 63.3 & 10 & $8.9 \times 10^{4}$ & $6.3 \times 10^{3} \pm 1.1 \times 10^{2 \mathrm{~b}}$ \\
Banana & 17 & 56.6 & 30 & $3.2 \times 10^{5}$ & $4.4 \times 10^{3} \pm 0.1 \times 10^{2 \mathrm{~b}}$ \\
Orange & 18 & 60 & 10 & $1.1 \times 10^{4}$ & $5.0 \times 10^{3} \pm 2.5 \times 10^{2 \mathrm{~b}}$ \\
\hline
\end{tabular}

Means of different superscript (a and b) considered significantly different at 95\%.

human consumption. The growth of Staphylococcus aureus in drinking yoghurt presents a potential public health hazard since many strains of Staphylococcus aureus produce entertoxins that cause food poisoning. The most common symptoms are nausea, vomiting and diarrhea. However in severe cases they may be accompanied by acute abdominal cramps. Symptoms usually occur 2-6 hours after ingestion of the contaminated food (Zuniga et al., 1999).

Inspection of data presented in Table (8) revealed that Pseudomonas and Aeromonas could be detected in plain and flavoured drinking yoghurt samples in a percentages of 23.3, $50,66.7,33.3$ and $40 \%$ with a mean values of $2 \times 10^{2} \pm 0.1 \times 10^{2}, 1.1 \times 10^{3} \pm 0.7 \times 10^{2}, 2.4 \times 10^{3} \pm 1.2$ $\times 10^{2}, 1.0 \times 10^{3} \pm 0.01 \times 10^{2}$ and $3.0 \times 10^{3} \pm 1.7 \times 10^{2}$ $\mathrm{CFU} / \mathrm{ml}$ of the examined plain, mango, strawberry, banana and orange samples, respectively. There was significant difference between the plain and different kinds of flavoured samples $(\mathrm{P}<0.05)$. Nearly similar finding were reported by Salminen, (1994) and Kraft (1995). Pseudomonas species are widely distributed in nature, they has been found in external environmental conditions surrounding dairy plant such as water, soil, sewage and air. These organisms represent the most common psychrotrophs that contaminated drinking yoghurt and cause a va- riety of defects including fruity, rancid, bitter and putrid flavour as well as color defects. With the extensive use of refrigerated storage of drinking yoghurt, the significance of Pseudomonas species in the spoilage of drinking yoghurt has increased dramatically due to production of proteinase, lipase, phospholipase $\mathrm{C}$ and glycosidase enzymes strongly damaging milk fat protein membrane which reflect on the quality of the finished products (Jayarao \& Yung, 1999). Pseudomonas species can be eliminated by pasteurization or UHT treatment, but their enzymes are able to resist heat treatment used for processing of raw milk and have been implicated in spoilage of ultra heat treated milk and other dairy products (Lira \& Nielsen, 1998, McKay, et al., 2000).

Salmonella and Yersinea species failed to be detected in all examined samples of drinking yoghurt. Bacillus cereus could be detected in flavoured drinking yoghurt samples in a percentages of $0,33.3,30,36.6$ and $23.3 \%$ with an average of $0,5.1 \times 10^{4} \pm 1.3 \times 10^{2}$ and $1.1 \times 10^{4} \pm$ $0.01 \times 10^{3}, 1 \times 10^{4} \pm 2.2 \times 10^{3}, 2.4 \times 10^{5} \pm 1.1 \times 10^{4}$ in examined plain, mango, strawberry, banana and orange samples, respectively (Table 9). Presence of Bacillus cereus in examined flavoured drinking yoghurt is not only of concern as a public health hazard, but also as a cause of eco-

Table 8: Statistical analytical results of Pseudomonas and Aeromonas counts in examined samples (n=30)

\begin{tabular}{llllll}
\hline \multirow{2}{*}{ Type } & \multicolumn{2}{c}{ Positive samples } & Min. & Max. & Mean \\
\cline { 2 - 3 } & No. & \% & & & \\
\hline Plain & 7 & 23.3 & 10 & $1.0 \times 10^{3}$ & $2 \times 10^{2} \pm 0.1 \times 10^{2 \mathrm{a}}$ \\
Mango & 15 & 50 & 100 & $3.0 \times 10^{4}$ & $1.1 \times 10^{3} \pm 0.7 \times 10^{2 \mathrm{~b}}$ \\
Strawberry & 20 & 66.7 & 100 & $6.8 \times 10^{4}$ & $2.4 \times 10^{3} \pm 1.2 \times 10^{2 \mathrm{~b}}$ \\
Banana & 10 & 33.3 & 50 & $1.2 \times 10^{4}$ & $1.0 \times 10^{3} \pm 0.01 \times 10^{2 \mathrm{~b}}$ \\
Orange & 12 & 40 & 60 & $6.6 \times 10^{4}$ & $3.0 \times 10^{3} \pm 1.7 \times 10^{2 \mathrm{~b}}$ \\
\hline
\end{tabular}

Means of different superscript (a and b) considered significantly different at 95\%. 
Table 9: Statistical analytical results of Bacillus cereus count in examined samples $(\mathbf{n}=30)$

\begin{tabular}{llllccc}
\hline \multirow{2}{*}{ Type } & \multicolumn{2}{c}{ Positive samples } & Min. & Max. & Mean \\
\cline { 2 - 3 } & No. & $\mathbf{\%}$ & & 0 & 0 & $0^{\mathrm{b}}$ \\
\hline Plain & 0 & 0 & 0 & $1.0 \times 10^{5}$ & $5.1 \times 10^{4} \pm 1.3 \times 10^{3 \mathrm{a}}$ \\
Mango & 10 & 33.3 & & 100 & $2.2 \times 10^{5}$ & $1.1 \times 10^{4} \pm 0.01 \times 10^{3 \mathrm{a}}$ \\
Strawberry & 9 & 30 & & 10 & $3.9 \times 10^{5}$ & $1.0 \times 10^{4} \pm 2.2 \times 10^{3 \mathrm{a}}$ \\
Banana & 11 & 36.6 & 10 & $1.9 \times 10^{3}$ & $2.4 \times 10^{5} \pm 1.1 \times 10^{4 \mathrm{a}}$ \\
Orange & 7 & 23.3 & & 10 & & \\
\hline
\end{tabular}

Means of different superscript (a and b) considered significantly different at 95\%.

nomic losses as off flavour, bitter taste and unpleasant odour (Salminen, 1994, Giffel, et al., 1996). Bacillus cereus is a food poisoning microorganisms widely distributed in nature. Its ability to form spores ensures survival of the organism through all stages of yoghurt processing. The organism has been well documented as being able to produce two distinct food poisoning. The emetic type is mainly characterized by acute attack of nausea and vomiting within 1-5 hours after food consumption while the diarrhoeagenic type is characterized by abdominal pain and diarrhea within 8-16 hours incubation and lasts 12-24 hours. Although the diseases are characterized by low mortality rate and short duration, the frequency of outbreak and severity of the symptoms make them as an important food borne hazard. Relatively high number of $B$. cereus need to be present in food to cause food illness. Food implicated with the syndrome outbreaks had counts ranging from $1 \times 10^{3}$ to $5 \times 10^{10} \mathrm{CFU} / \mathrm{g}$ with an average of $1 \times 10^{5} \mathrm{CFU} / \mathrm{g}$ (Rossland et al., 2005).

Results concerning the survival of Listeria monocytogenes in plain and flavoured strawberry yoghurt stored at $4 \mathrm{C}$ inoculated at $6.6 \times$ $10^{5} \mathrm{CFU} / \mathrm{ml}$ are summarized in Table (10). The achieved results revealed that Listeria monocytogenes was slightly decreased in count in plain yoghurt from $6.6 \times 10^{5}$ to $2.5 \times 10^{5} \mathrm{CFU} / \mathrm{ml}$ after 30 days of cold storage and $\mathrm{pH}$ was reduced from 4.2 to 3.0 while in flavoured strawberry yoghurt Listeria monocytogenes was decreased from $6.6 \times 10^{5}$ to $2.6 \times 10^{5} \mathrm{CFU} / \mathrm{ml}$ with $\mathrm{pH} 4.25$ to 3.11 during cold storage. There was no change in the surviving populations of Listeria monocytogenes in both plain and flavoured drinking yoghurt. The population of Listeria monocytogenes remained unchanged for up to 10 days. There was reduction in viable populations after 10 days and up to 30 days of storage averaged $4.1 \times 10^{5} \mathrm{CFU} / \mathrm{ml}$. This finding show that Listeria monocytogenes can survive at $\mathrm{pH}$ as low as 3.1. During cold storage plain and strawberry flavoured yoghurt exhibited the same decline in surviving populations. Nearly similar findings were reported by Zuniga et al. (1995), Benkerroum et al. (2002) and Barrantes et al. (2004). The $\mathrm{pH}$ of the samples was changed from 4.62 and 4.25 to 3 and 3.11 for both plain and flavoured drinking yoghurt, respectively. The decrease of $\mathrm{pH}$ in drinking yoghurt can be explained by the persistant metabolic activity of lactic acid bacteria during cooling (Berrocal et al., 2005). Acid resistance and

Table 10: Survival of Listeria monocytogenes in plain and flavoured yoghurt inoculated at $6.6 \times 10^{5}$ $\mathrm{CFU} / \mathrm{ml}$ and stored at $4^{\circ} \mathrm{C}$ for 30 days

\begin{tabular}{lllll}
\hline \multirow{2}{*}{$\begin{array}{l}\text { Storage } \\
\text { time/day }\end{array}$} & $\mathbf{p H}$ & $\mathbf{C F U} / \mathbf{m l}$ & \multicolumn{2}{c}{ Flavoured with strawberry } \\
\cline { 2 - 5 } & 4.26 & $6.60 \times 10^{5}$ & $\mathbf{p H}$ & $\mathbf{C F U} / \mathbf{m l}$ \\
\hline 0 & 4.12 & $6.60 \times 10^{5}$ & 4.25 & $6.60 \times 10^{5}$ \\
5 & 4.00 & $6.50 \times 10^{5}$ & 4.13 & $6.60 \times 10^{5}$ \\
10 & 3.92 & $4.93 \times 10^{5}$ & 4.00 & $6.50 \times 10^{5}$ \\
15 & 3.81 & $3.52 \times 10^{5}$ & 3.95 & $4.81 \times 10^{5}$ \\
20 & 3.60 & $3.88 \times 10^{5}$ & 3.51 & $3.45 \times 10^{5}$ \\
25 & 3.00 & $2.50 \times 10^{5}$ & 3.40 & $3.30 \times 10^{5}$ \\
30 & & & 3.11 & $2.60 \times 10^{5}$ \\
\hline
\end{tabular}


acid tolerance bacteria are important virulence determinants that contribute to the survival and pathogenicity of infectious food borne pathogens to cause disease. Acid resistance increases the portion of the population that survives gsastric infectivity once the pathogens attaches to the intestinal tract (Peterson et al., 1989, Jayaro \& Yung, 1999). Although there have been no reports of the isolation of Listeria monocytogenes from drinking yoghurt, the possibility of contamination exists. A potential health hazard could arise if sufficient number of Listeria monocytogenes contaminate drinking yoghurt after heat treatment under unhygienic measures or improper sanitary methods during production and handling.

\section{CONCLUSION}

One can realize from the results achieved that flavoured drinking yoghurt still harbor undesirable organisms that affect its quality and utility. Therefore, to improve the quality of the products good hygienic measures should be adopted during milk storage, added ingredients (fruit mixes, flavours, stabilizers and emulsifiers), periodical inspection of the dairy plants as well as the control of the final product during production, packaging and distribution.

\section{REFERENCES}

Adhikari, K., Mustapha, A., Grun, I. \& Fernando, L. 2000. Viability of microencapsulated Bifidobacteria in set yoghurt during refrigerated storage. J. Dairy Sci., 83 (2): 146-151.

Al-Kadamany, E., Toufeili, I., Khattar, M., AbouJawdeh, Y., Harakeh, S. \& Haddad, T. 2002. Determination of shelf life of concentrated yoghurt (labneh) produced by in-bag straining of set yoghurt using hazard analysis. J. Dairy Sci., 85 (5): 1023-1030.

Armesto, M. \& Alastair, S. 1997. Temperature characterization of Psychrotrophic and Mesophilic Bacillus species in fermented milks. $\mathrm{J}$ Dairy Res., 64 (1): 5-8.

Barrantes, Y., Railey, D., Arias, M \& Chaves, C. 2004. Evaluation the effect of probiotic culture added to commercial yoghurt over a known population of Listeria monocytogens. Arch Latinoam Nut., 52 (3): 293-297.

Bartram, H. P., Scheppach, W., Gerlach, S. \& Kasper, H. 1994. Does yoghurt enriched with Bifidobacterium longum affect colonic microbiology and fecal metabolites in healthy subjects. Am. J. Clin. Nutr., 59 (2): 428-432.

Beal, C., Skokanova, J., Latrille, E., Martin, N. \& Corrieu, G. 1999. Combined effects of culture conditions and storage time on acidifica- tion and viscosity of stirred yoghurt. J Dairy Sci., 82 (3): 673-681.

Benkerroum, J., Dubel, H. \& Mimoun, L. 2002. Behaviour of Listeria monocytogenes and Staphylococcus aureus in yoghurt fermented with thermophilic starter. J Food Prot., 65 (5): 799-805.

Berrocal, D., Arias, M., Henderson, M. \& Wong, E. 2005. Evaluation of the activity of probiotic culture over Listeria monocytogenes during the production and storage of yoghurt. Arch. Latinoam Nut., 53 (2): 375-380.

Chapman, G.J. 2003. Natural occurrence of mycotoxins in foods. J. Ann. Microbiol., 20 (3): 333-339.

Collins, C.H., Lyne, P. \& Grange, J. 1995. Microbiological Methods. $7^{\text {th }}$ ed. Butter worth, D. (Ed.) Academic press, London, p. 287-300.

De Moreno, L. \& Perdigon, G. 2004. Yoghurt feeding inhibits promotion and progression of experimental colorectal cancer. Med. Sci. Monit., 10 (2): 96-104.

Donald, A. \& George, W. (1992). Yersinia. In: Vanderzent, C. \& Splittstoesser, D. (eds). Compendium of Methods for Microbiological Examination of Food. $3^{\text {rd }}$ ed. American Public Health Association, Washington, DC. pp. 313-357.

Egyptian Standard 2005. Egyptian Organization for Standardization and Quality. flavoured yoghurt. No. 1650.

Elzataar, M., Pasarell, L., Mcginnis, M. \& Salkin, I. 1990. Yeast identification in food. J. Clin.Microbiol., 38 (10): 1938-1941.

Flowers, R.S., Jeans, Y., Andrewa, W.H. \& Bailey, J.S. 1992. Salmonella. Chapter 25. In: Vanderzant, C. \& Splittoesser, D. (eds). Compendium of Methods for Microbiological Examination of Food. $3^{\text {rd }}$ ed. American Public Health Association, Washington, DC, USA. pp. 560-582.

Gabriela, P., Carlos, V. \& Rachid, M. 1998. Antitumor activity of yoghurt: study of possible immune mechanisms. J. Dairy Res., 65 (2): 129-138.

Garbutt, J. 1998. Food Borne Diseases and Food Poisoning. In: Essential of Food Microbiology (Garbut, J. ed.). Arlond, London Press, pp. 134-172.

Giffel, M., Beumer, R., Bonestroo, M. \& Rombouts, F. 1996. Occurrence of Bacillus cereus in dairy processing plants. Netherlands Milk and Dairy J., 50 (3): 479-492.

Gilliland, S. 1998. Fermented Milks and Probiotics. In: Applied Dairy Microbiology (Marth, E. \& Steele, J. eds). University of Wisconsin, New York, Marcel Dekker Inc, p. 195-212. 
Gourama, H. \& Bullerman, B. 1995. Detection of molds in food and feed. J Food Prot., 58 (12):1395-1404.

Graciela, L., Garrote, N. \& Graciela, D. 2001. Chemical and microbiological characterization of fermented milks. J. Dairy Res., 68 (3): 639-652.

Granum PE. 1997. Bacillus cereus. In Food Microbiology: Fundamentals and Frontiers. (Doyle, M.P., Beuchat, L.R. \& Montville, T.D. eds.) ASM Press, Washington, D.C., USA, p. 327336.

Harte, F., Luedecke, L., Swanson, B. \& Barbosa, V. 2003. Low fat set yoghurt from milk sunjected to combination of high presseur and thermal processing. J. Dairy Sci., 86 (10): 1074-1082.

Hitchins, A.D., Hartman, P.A. \& Tood, E.C. 1992. Coliforms Escherichia coli and its Toxins. Chapter 24. In: Vanderzant, C. \& Splittstoesser, D. (eds.) Compendium of Methods for Microbiological Examination of Food. $3^{\text {rd }}$ ed. American Public Health Association, Washington, DC, USA.

ICMSF "International Committee on Microbiological Specification for Foods" 1996. Microorganisms in Foods: Their Significance and Method of Enumeration. $2^{\text {th }}$ ed. University of Toronto Press, Toronto, Canada, p. 564-790.

Jayarao, B. \& Yung, L. 1999. A study on the prevalence of gram-negative bacteria in bulk tank milk. J. Dairy Sci., 82 (12): 2620-2624.

Kozlowska K., Wierzbicka E., Brzozowska A. \& Roszkowski W. 2002. Consumption of food products by the elderly living in different environments. J. Nut. Health, 16 (1): 27-30.

Kora, E., Souchon, R., Latrille, E., \& Marin, M. 2004. Composition rather than viscosity modifies the aroma of flavoured stirred yoghurt. $\mathrm{J}$ Agric. Food Chem., 52 (11): 3048-3056.

Kraft, A.A. 1995: Spoilage of Dairy Products, Fruits, Vegetables and other Foods. In: Psychrotrophic Bacteria in Foods. (Kraft, A.A. Ed.) CRC Academic Press, p. 115-131.

Kurmann, J., Rasic, J. \& Kroger, M. 2000. Encyclopedia of Fermented Fresh Milk Products. An International Inventory of Fermented Milk, Cream Butter Milk, Whey and Related Products. Van Nostrand, New York, pp. 60-75.

Li, F. \& Li, Y. 1998. Study on the contamination level and the tolerable limit of mould and yeast in yoghurt. Milchwissenschaft, 27 (4): 257-258.

Lira, C.E. \& Nielsen, S.S. 1998: Effect of Psychrotrophic microorganisms on the plasmin system in milk. J. Dairy Sci., 81 (3): 901-908.

Lodder, J. 1990. The Yeast a Taxonomic Study. North Holland Publishing Amesterdam, $3^{\text {rd }}$ ed. Academic Press London, p. 200-309.
Lubbers, S., Decourage, N., Valle, N \& Guichard, E. 2004. Flavour release and reology behaviour of strawberry flavoured yoghurt. J Agric. Food Chem., 52(5): 3077-3082.

Marshall, R.T. 1992. Standard Methods for the Examination of Dairy Products. $15^{\text {th }}$ ed. Am. Publ. Health Assoc. Inc., Washington, DC, p. 232-363.

Martin, N, Skokanova, J. \& Corrieu, G. 2004. Influence of fermentation and storage conditions on the organoleptic and microbiological properties of plain low fat stirred yoghurts. J. Sensory Studies, 14(6): 139-160.

Messer, J.W., Midura, T.F. \& Peller, T. 1992. Sampling plans, sample collection, shipment and preparation for analysis. Chapter 2. In: Vanderzont C. \& Splittstoesser, D.F. (eds.). Compendium of Methods for Microbiological Emamination of Foods. $3^{\text {rd }}$ ed. American Public Health Association, Washington, D.C., USA.

Moreno, D. 2005. Drinking yoghurt and inhibition of colo-rectal cancer. Med. Sci. Monit., 11 (1): 96-104.

Pereg, D., Kimihi, O., Tiroshi, A. \& Lishner, M. 2005. The effect of fermented yoghurt on the prevention of diarrhea in a healthy adult population. Amm. J. Infect. Control, 33 (2): 122-125.

McKay, D., Dieckelmann, M. \& Beacham I. 2000. Degradation of triglycerides by a Pseudomonad isolated from milk: the roles of lipase and esterase studied using recombinant strains over-producing, or specifically deficient in these enzymes. J. Appl. Bacteriol., 78 (1): 3139.

Ott, A., Hugi, A., Baumgartner, M. \& Chaintreau, A. 2000. Sensory investigation of yoghurt flavour perception: Mutual influence of volatiles and acidity. J Dairy Sci., 83 (9): 1946-1951.

Peterson, W., Mackowiak, P., Barnett, C. \& Haley, M. 1989. The human gastric bactericidal barrier: Mechanisms of action, relative antibacterial activity and dietary influence. J. Infect. Dis., 159 (4): 979-983.

Pitt, J.I. \& Hocking, A.D. 1997: Fungi and Food Spoilage. Blackie Academic and Professional Press, Chapman and Hall, London, pp. 413455.

Rama, R., Sally, G., David, H. \& Vishnu, C. 1998. Efficacy of API 20 C systems for identification of yeast isolates. J. Clin. Microbial., 46 (11): 3396-3398.

Ray, B. 2004. Normal Microbiological Quality of Fermented Foods and its Significance. In: Fundamental Food Microbiology Ray, B. (ed.) $3^{\text {rd }}$ ed. CRC Academic Press, New York, pp. 43-83. 
Robert, A.S. 1997. Advances in Food and Feed Mycology. Proceeding of the World Congress on Food Hygiene (WAVFH) Netherlands, p. 248-369.

Robinson, R.K. 1990. Dairy Microbiology $2^{\text {nd }}$ ed. Chapman, C. \& Hall, M. (Eds.) Academic Press, London, pp. 230-281.

Rodriguez, A., Diaz, P., Gonzaley, P. \& Delattorie, H. 2003. Microorganisms of food hygiene interest in commercial yoghurt in the canary Islands. Alimentaria, 222 (9): 555-558.

Rossland, E., Langsrum, T., Granum, P. \& Sorhaug, T. 2005. Production of antimicrobial metabolites by strains of Lactobacillus or Lactococcus co-cultured with Bacillus cereus in milk. Int. J Food Microbiol., 98 (2): 193-200.

Salminen, S. 1994. Fermented whey drink and set yoghurt product manufactured using lactobacillus strain. J. Food Technol., 48 (6): 112116.

Samson, R., Hoekestra, E., Frisvad, J. \& Filtenberg, O. 1995. In: (onsen, E.D. \& Looijen, B. (eds). Introduction to Food Borne Fungi. $4^{\text {th }}$ ed. Central Bureau Vor Schimmel Cultures. Wageningen, Netherlands. p. 616-655.

Seppo, L., Juhinen, T. \& Poussa, L. 2003. A fermented milk high in bioactive peptides has a blood pressure-lowering effect in hypertensive subjects. Am J Clin. Nutr. ,77 (1): 326330.

Spreer, E. \& Mixa, A. 1998. Milk and Dairy Product Technology. $2^{\text {nd }}$ ed. Academic Press London, pp. 341-363.
SPSS, four windows 1993. Release 6.0, June 17, 1993 copyright (C. SPSS Inc. 1989-1993).

Tipparaju, S., Sadhana, R. \& Peter, S. 2004. Survival of Listeria monocytogenes in flavoured soy and dairy products stored at $80^{\circ} \mathrm{C}$. J Food Protect., 67 (2): 378-382.

Varnam, A. \& Sutherland, J. 1994. Milk and Milk Products Technology, Chemistry and Microbiology. $1^{\text {st }}$ ed. Chapman and Hall, Academic press London, pp. 301-380.

WHO, World Health Organization 2000. Surveillance program for control of food borne infection and intoxicationin Europe. Newsletter No. 63 March, 2000.

Wollowski, I., Seung, T., Bakanisky, C. \& Beatrice, L. 1999. Bacteria Used for the Production of Yoghurt Inactivate Carcinogens and Prevent DNA Damage in the Colon of Rats. Pakistan J. Nut., 129 (1): 77-82.

Yuceer, Y., Wilson, J. \& White, C. 2001. Formulations and processing of yoghurt affect the microbial quality of carbonated yoghurt. J. Dairy Sci., 84 (1): 7-11.

Zuniga, E., Lopez, M. \& Garzia, L.M. 1995. Survival of Listeria monocytogenes in milk fermented with starter culture for making yoghurt. Rev. Latinoam Microbiol., 37 (3): 257265.

Zuniga, E., Sanchez, Z.M., Garza, M. \& Ortigoza, F. 1999. Behaviour of Staphylococcus aureus in milk fermented with a yoghurt starter culture. Rev. Sci. Technol., 41 (1): 5-10.

\section{دراسة مقارنة على الحمل الميكروبي لمشروب اللبن الزبادي المصري المُطَعم وغير الُمَعم}

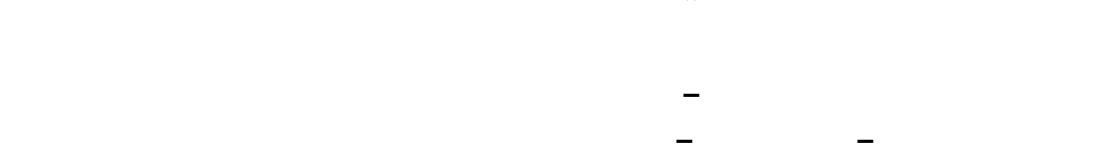

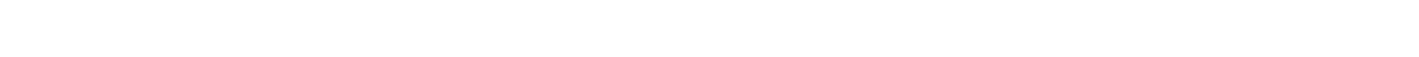

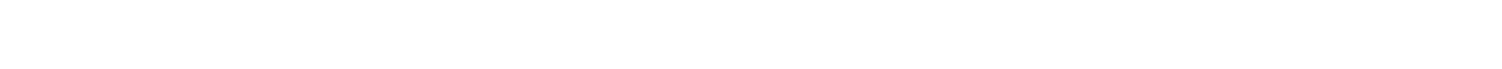

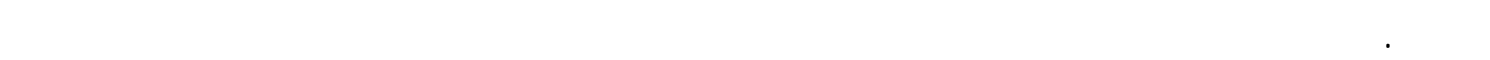

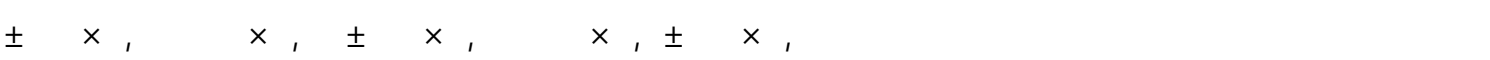

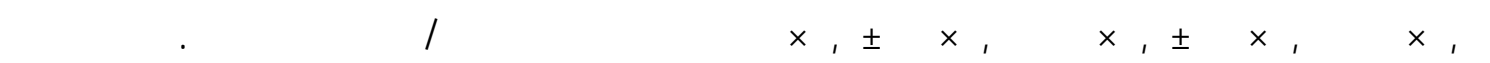

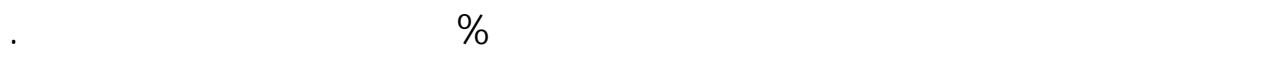

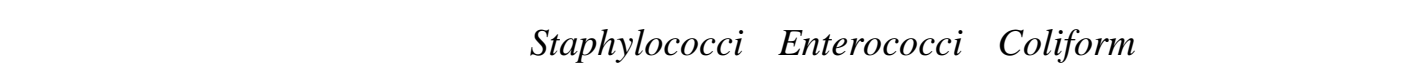

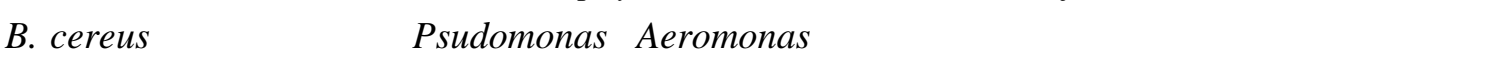

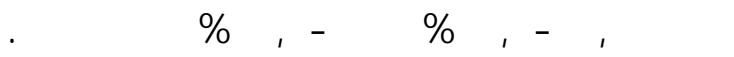

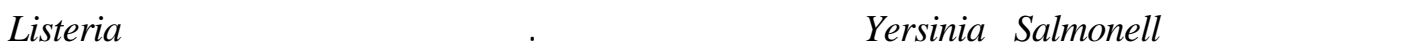
monocytogenes

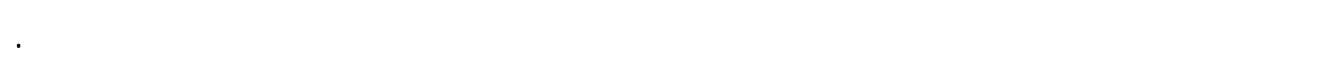

